\title{
Facile Synthesis of Novel Chiral Bicyclic Thioureas and Their Crystal Structures
}

\author{
Ping-An Wang*, Hui-Fang Nie, Lin-Jie Yan, Sheng-Yong Zhang \\ Department of Medicinal Chemistry, School of Pharmacy, Fourth Military Medical University, Xi'an, China \\ Email: *ping_an1718@yahoo.com.cn
}

Received December 23, 2011; revised January 27, 2012; accepted February 5, 2012

\begin{abstract}
The novel well-defined chiral bicyclic thioureas based on enantiopure unsymmetric cis-2,5-disustituted pyrrolidine skeleton were firstly synthesized and fully characterized by their ${ }^{1} \mathrm{H}$ NMR, ${ }^{13} \mathrm{C}$ NMR and HRMS. Their absolute configurations were also determined by single-crystal $\mathrm{X}$-ray analysis.
\end{abstract}

Keywords: Chiral Bicyclic Thiourea; cis-2,5-Disubstituted Pyrrolidine; X-Ray Analysis

\section{Introduction}

The chiral thioureas undoubtedly play an important role in asymmetric catalysis. On one hand, chiral bifunctional thioureas are excellent organocatalysts [1-5] due to their unique dual activations of both of electrophile and nucleophile, and now it is known as the term of hydrogenbond-donor organocatalysts [6-8]. On the other hand, chiral thioureas were used as efficient ligands in Pdcatalyzed C-C bond formations [9-12] and Rh-catalyzed asymmetric reactions $[13,14]$ and show moderate to good enantioselectiveties. Until now, most of these chiral thioureas are derived from cinchona alkaloids [15-17], 1, 2-cyclohexyldiamine [18,19], binaphthol [20,21], glucose [22,23] and $L$-proline [24-26], therefore, the exploration of preparation and application of novel chiral thioureas based on the other backbones is a challenging and interesting objective.

In our previous research work $[27,28]$, we established a facile synthetic route to enantiopure unsymmetric cis-2, 5-disubstituted pyrrolidines containing hydroxyl-diamino skeleton (Figure 1), and herein we wish to report an efficient synthesis of novel chiral bicyclic thioureas based on the skeleton of these enantiopure pyrrolidines.

\section{Results and Discussion}

The chiral cis-2,5-disustituted pyrrolidines $\mathbf{1 a}$ and $\mathbf{1 b}$ were obtainned from meso-diethyl-2,5-dibromoadipate and (S)-(-)-1-phenylethylamine through six steps including cyclization, monohydrolysis, amidation, Grignard reaction, reduction and debenzylation [27]. The overall yield of six steps is about $30 \%$.

*Corresponding author.
With the chiral cis-2,5-disustituted pyrrolidines 1a and $\mathbf{1 b}$ in hand, the synthesis of novel bicyclic thioureas 2 was investigated. Initially, the compound 1a was directly used to react with thiophosgene in $\mathrm{CH}_{2} \mathrm{Cl}_{2}$ by using triethylamine (TEA) as base (Scheme 1), and the reaction result is complex. The chiral bicyclic thiourea 2a was obtained only in $26 \%$ yield after purification by flash column chromatography. Because pyrrolidine 1a possesses hydroxyl-diamino group and thiophosgene is a very active reagent, maybe thiophosgene attacks these three active reaction sites in pyrrolidine 1a at the same time to result in some competing side reactions. In order to obtain the chiral bicyclic thiourea $\mathbf{2 a}$ in high yield, the hydroxyl group in pyrrolidine 1a should be protected.

Usually, the hydroxyl group was converted into its silyl ether in the organic protection strategy and trimethylsilyl (TMS) ether is readily stable in the presence of $\mathrm{Et}_{3} \mathrm{~N}, 2,6$-lutidine and $\mathrm{N}, \mathrm{N}$-diisopropylethylamine (DIPEA, Hünig's base). The chiral pyrrolidine 1a firstly reacted with trimethylsilyl trifluoromethanesulfonate (TMSOTf) to give TMS-protected pyrrolidine $\mathbf{3 a}$ in quantitative yield, and which was immediately used to react with thiophosgene to furnish TMS-protected thiourea 4a (Scheme 2). In this key step, the reaction conditions were optimized and the results were shown in Table 1. It was found that in the presence of Hünig's base, TMS-protected thiourea 4a was obtained in $89 \%$ crude yield by using $\mathrm{CH}_{2} \mathrm{Cl}_{2}$ as solvent. Then $\mathbf{4 a}$ was deprotected by tetrabutylammonium fluoride (TBAF) in anhydrous THF to release the novel chiral bicyclic thiourea 2a in excellent yield $(94 \%)$, and 2a was fully characterized by its ${ }^{1} \mathrm{H}$ NMR, ${ }^{13} \mathrm{C}$ NMR and HRMS.

To our satisfaction, the suitable crystals of 2a were grown from hexane-EtOAc for X-ray diffraction analysis 


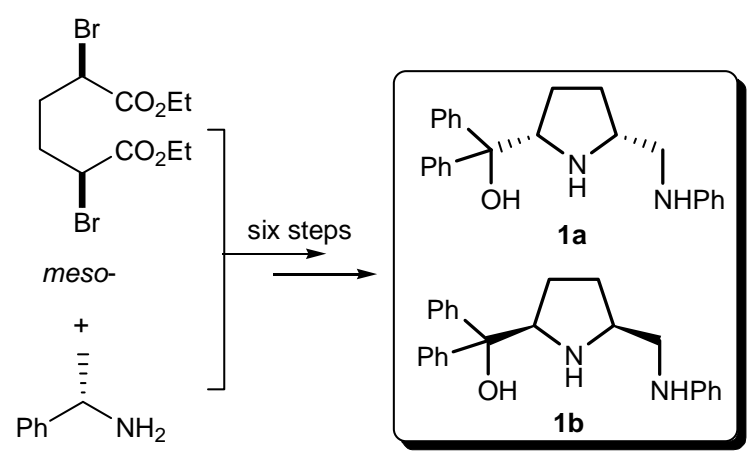

Figure 1. The synthesis of pyrrolidines $1 \mathrm{a}$ and $\mathbf{1 b}$.

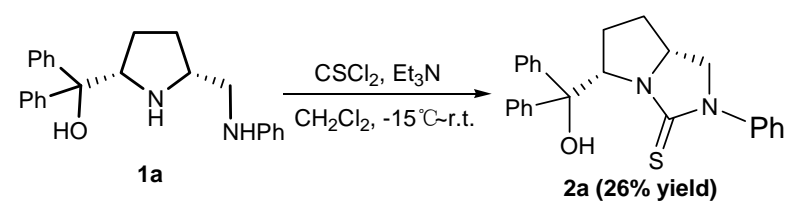

Scheme 1. The direct synthesis of $2 a$ from $1 a$.
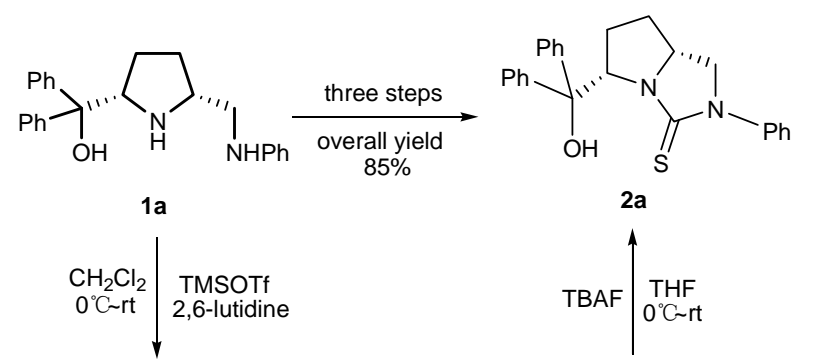

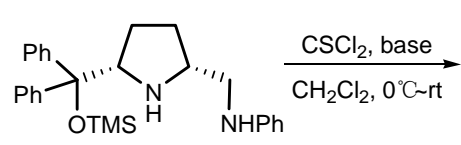

$3 a$

Scheme 2 . The synthesis of $2 \mathrm{a}$ by three steps.

Table 1. The optimization of the reaction conditions of $3 a$ with thiophosgene.

\begin{tabular}{ccccc}
\hline Entry & Base $^{\mathrm{a}}$ & Solvent & Temp. $\left[{ }^{\circ} \mathrm{C}\right]$ & ${\text { Yield }[\%]^{\mathrm{b}}}^{\circ}$ \\
\hline 1 & TEA & THF & r.t. & 52 \\
2 & DIPEA & THF & r.t. & 67 \\
3 & TEA & $\mathrm{CH}_{2} \mathrm{Cl}_{2}$ & $0 \sim$ r.t. & 60 \\
$\mathbf{4}$ & DIPEA & $\mathbf{C H}_{2} \mathbf{C l}_{2}$ & $\mathbf{0} \sim$ r.t. & $\mathbf{8 9}$ \\
\hline
\end{tabular}

${ }^{\mathrm{a}} 4$ eq. base was used in all entries; ${ }^{\mathrm{b}} \mathrm{Crude}$ yield of product based on $\mathbf{3 a}$.

(Figure 2). The chiral bicyclic thiourea 2a adopted monoclinic system and its space group is $P 21$. From the $\mathrm{X}$-ray structure of $\mathbf{2 a}$, the pyrrolidine ring is obviously in cis-configuration, which indicates that the configurations of 1a were retained in the synthetic process. The two five-membered rings (N1-C14-C15-C16-C17 and N1C17-C18-N2-C19) in 2a all adopt envelope conforma-

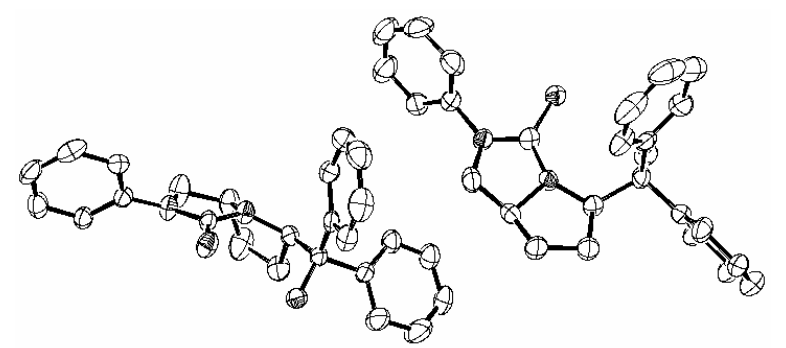

Figure 2. The X-ray structure of chiral bicyclic thiourea 2a, $\mathrm{H}$ atoms were omitted for clarity.

tion, and the absolute configurations of two chiral carbon atoms $\mathrm{C} 14$ and $\mathrm{C} 17$ in pyrrolidine ring are $R$ and $S$ respectively.

More interestingly, one cell of X-ray structure of 2a contains two complete molecules, but the bond lengths, angles and torsion angles of these two molecules are not same. For example, two intramolecular hydrogen bonds between hydroxyl and thionyl groups were found in the X-ray structure of 2a, but the lengths and angles of these two intramolecular hydrogen bonds are different, the length of H1---S1 $(2.290 \AA)$ is $0.039 \AA$ shorter than H2---S2 (2.329 $\AA$ ), and the angle of O2-H2---S2 $\left(161.28^{\circ}\right)$ is $9.41^{\circ}$ bigger than $\mathrm{O} 1-\mathrm{H} 1--\mathrm{S} 1 \quad\left(151.87^{\circ}\right)$. Some selected bond lengths, angles and X-ray crystallographic parameters of $\mathbf{2 a}$ are listed in Table 2. The enantiomer $\mathbf{2 b}$ was synthesized following the same procedure as $\mathbf{2 a}$.

The chiral thioureas $\mathbf{2}$ have several attractive features. First, the two incorporated binding sites in $\mathbf{2}$ should afford a rigid backbone for coordination with metals. Second, the steric and electronic properties of chiralthioureas 2 can be easily modified by fine-tuning the substituents. Third, the chiral thioureas 2 enjoy a good stability to air and moisture. In addition, the hydroxyl group in $\mathbf{2 a}$ and 2b can provide a hydrogen-bond donor, and the thionyl group can serve as a hydrogen-bond acceptor, so, these chiral bicyclic thioureas 2 should have potential utilities to be used as ligands or organocatalysts in asymmetric catalysis.

\section{Experimental}

${ }^{1} \mathrm{H}$ and ${ }^{13} \mathrm{C}$ NMR spectra were measured in $\mathrm{CDCl}_{3}$ solutions on a Bruker AV-300 or AV-500 spectrometer using TMS as an internal reference. Coupling constant $(J)$ values are given in Hz. Mass spectra and High-resolution mass spectra were performed on a VG Micromass 7070F Mass Spectrometer with ES ionization (ESI). Crystal structure determination of compounds 2a was carried out on a Bruker SMART CCD Single Crystal X-ray Diffractometer equipped with graphite-monochromatized $\mathrm{Mo}_{K \alpha}$ $(\lambda=0.71073 \AA)$ radiation. The structure was solved by direct methods and refined on $F^{2}$ by full-matrix leastsquares methods using SHELX-97. Melting points are 
Table 2. Some selected crystal data, bond lengths and angles of $2 a$.

\begin{tabular}{|c|c|c|c|c|c|}
\hline Parameter & Compound 2a & Bond & Length $[\AA ̊]$ & Bond & Angle $\left[{ }^{\circ}\right]$ \\
\hline Empirical formula & $\mathrm{C}_{25} \mathrm{H}_{24} \mathrm{~N}_{2} \mathrm{O} \mathrm{S}$ & S1-C19 & $1.667(5)$ & N1-C19-S1 & $128.9(3)$ \\
\hline Molecular weight & 400.52 & N1-C19 & $1.351(5)$ & N2-C19-S1 & $122.7(4)$ \\
\hline Crystal size $\left[\mathrm{mm}^{3}\right]$ & $0.31 \times 0.29 \times 0.18$ & $\mathrm{~N} 2-\mathrm{C} 19$ & $1.356(5)$ & N1-C19-N2 & $108.4(4)$ \\
\hline Temperature $[\mathrm{K}]$ & $296(2)$ & $\mathrm{N} 1-\mathrm{C} 17$ & $1.478(6)$ & C19-N2-C18 & $112.0(4)$ \\
\hline Crystal color & Colorless block & N2-C18 & $1.465(7)$ & N2-C18-C17 & $103.0(4)$ \\
\hline Space group & $P 21$ & $\mathrm{C} 17-\mathrm{C} 18$ & $1.498(5)$ & N1-C17-C18 & $103.3(4)$ \\
\hline Crystal system & Monoclinic & $\mathrm{N} 1-\mathrm{C} 14$ & $1.464(5)$ & $\mathrm{C} 18-\mathrm{C} 17-\mathrm{C} 16$ & $118.1(5)$ \\
\hline$a[\AA]$ & $9.708(2)$ & $\mathrm{C} 14-\mathrm{C} 15$ & $1.540(6)$ & $\mathrm{C} 17-\mathrm{C} 16-\mathrm{C} 15$ & $105.9(4)$ \\
\hline$b[\AA]$ & $13.668(3)$ & $\mathrm{C} 15-\mathrm{C} 16$ & $1.524(8)$ & $\mathrm{C} 16-\mathrm{C} 15-\mathrm{C} 14$ & $104.1(4)$ \\
\hline$c[\AA]$ & 15.994(3) & $\mathrm{C} 16-\mathrm{C} 17$ & $1.518(8)$ & N1-C14-C15 & $102.9(3)$ \\
\hline$\alpha\left[^{\circ}\right]$ & 90 & $\mathrm{~N} 2-\mathrm{C} 20$ & $1.423(6)$ & C19-N1-C14 & $133.0(4)$ \\
\hline$\beta\left[^{\circ}\right]$ & $95.284(4)$ & C7-C14 & $1.539(6)$ & C14-N1-C17 & $104.0(3)$ \\
\hline$\gamma\left[^{\circ}\right]$ & 90 & $\mathrm{O} 1-\mathrm{C} 7$ & $1.417(6)$ & $\mathrm{C} 14-\mathrm{C} 7-\mathrm{O} 1$ & $110.9(4)$ \\
\hline$U\left[\AA^{3}\right]$ & $2113.2(8)$ & O1-H1---S1 & 2.290 & O1-H1---S1 & 151.87 \\
\hline$\mu\left(\mathrm{Mo}_{\mathrm{K} \alpha}\right)[\AA]$ & 0.71073 & $\mathrm{~S} 2-\mathrm{C} 50$ & $1.667(5)$ & N3-C50-S2 & $128.4(4)$ \\
\hline$D_{\text {calc }}\left[\mathrm{Mg} \cdot \mathrm{m}^{-3}\right]$ & 1.259 & $\mathrm{~N} 3-\mathrm{C} 50$ & $1.355(6)$ & $\mathrm{N} 4-\mathrm{C} 50-\mathrm{S} 2$ & $124.6(4)$ \\
\hline$Z$ & 4 & $\mathrm{~N} 4-\mathrm{C} 50$ & $1.358(6)$ & $\mathrm{N} 4-\mathrm{C} 50-\mathrm{N} 3$ & $107.1(4)$ \\
\hline$F(000)$ & 848 & $\mathrm{~N} 3-\mathrm{C} 42$ & $1.472(6)$ & N4-C43-C42 & 101.1(4) \\
\hline$\theta$ range $\left[{ }^{\circ}\right]$ & $1.28-25.10$ & N4-C43 & $1.461(6)$ & C50-N3-C42 & $110.6(4)$ \\
\hline Absorption coefficient $\left[\mathrm{mm}^{-1}\right]$ & 0.172 & $\mathrm{C} 42-\mathrm{C} 43$ & $1.500(7)$ & $\mathrm{N} 3-\mathrm{C} 42-\mathrm{C} 43$ & $100.9(4)$ \\
\hline Completeness to $\theta=25.10[\%]$ & 99.4 & N3-C39 & $1.473(5)$ & $\mathrm{N} 3-\mathrm{C} 42-\mathrm{C} 41$ & $102.8(4)$ \\
\hline Absolute structure parameter & $-0.10(10)$ & $\mathrm{C} 39-\mathrm{C} 40$ & $1.559(6)$ & C50-N3-C39 & 137.1(4) \\
\hline Reflections collected & 10761 & $\mathrm{C} 40-\mathrm{C} 41$ & $1.525(7)$ & $\mathrm{C} 42-\mathrm{C} 41-\mathrm{C} 40$ & $105.5(4)$ \\
\hline Unique reflections & 6718 & $\mathrm{C} 41-\mathrm{C} 42$ & $1.494(7)$ & C41-C40-C39 & $107.2(4)$ \\
\hline$R_{\text {int }}$ & 0.0416 & N4-C44 & $1.446(6)$ & N3-C39-C40 & 106.5 \\
\hline$R_{1}, \mathrm{w} R_{2}[I>2 \sigma(I)]$ & $0.0482,0.1161$ & C32-C39 & $1.577(6)$ & C42-N3-C39 & $109.7(4)$ \\
\hline$R_{1}$, w $R_{2}$ (all data) & $0.0970,0.1435$ & $\mathrm{O} 2-\mathrm{C} 32$ & $1.417(6)$ & O2-C32-C39 & 107.9(4) \\
\hline Goodness-of-fit on $F^{2}$ & 1.068 & O2-H2---S2 & 2.329 & O2-H2---S2 & 161.28 \\
\hline
\end{tabular}

uncorrected and expressed in degree Celsius. Optical rotations analyses were performed on a Perkin-Elmer Model 343 Polarimeter. TMSOTf was prepared from trimethylsilyl chloride and trifluoromethanesulfonic acid by Corey's procedure [29]. Solvents and reagents were purified and dried by standard methods prior to use. All reactions involving air or moisture sensitive species were performed in oven-dried glassware under inert atmosphere. Products were purified by flash column chromatography on silica gel purchased from Qingdao Haiyang Chemical Co. Ltd.

\subsection{Direct Synthesis of 2a from Unprotected Pyrrolidine 1a and Thiophosgene}

The chiral pyrrolidine 1a $(1.08 \mathrm{~g}, 3.0 \mathrm{mmol})$ was dissolved in $40.0 \mathrm{~mL}$ anhydrous $\mathrm{CH}_{2} \mathrm{Cl}_{2}$ and $\mathrm{Et}_{3} \mathrm{~N}(3.6 \mathrm{~mL}$, $25.6 \mathrm{mmol}$ ) and the solution was cooled to $-15^{\circ} \mathrm{C}$ by ice-salt bath. Thiophosgene $(0.3 \mathrm{~mL}, 3.9 \mathrm{mmol}$, CAUTION! Thiophosgene is a highly corrosive and toxic reagent) was added dropwise to the mixture and the reaction mixture was stirred at $-15^{\circ} \mathrm{C}$ for $45 \mathrm{~min}$, then, it was continued to stir at room temperature (r.t.) overnight. The reaction was examined by thin layer chromatography (TLC). After the reaction was finished, the mixture was cooled to $0^{\circ} \mathrm{C}$ and quenched by addition of $5.0 \mathrm{~mL} \mathrm{H} \mathrm{H}_{2} \mathrm{O}$. The solvents were removed under reduced pressure and the residue was dissolved in $100.0 \mathrm{~mL}$ ethyl acetate. The organic layer was washed by water $(2 \times 20 \mathrm{~mL})$ and brine $(2 \times 20 \mathrm{~mL})$, and dried over anhydrous $\mathrm{Na}_{2} \mathrm{SO}_{4}$. The solvent was evaporated under reduced pressure to give the crude product as yellow foam which was purified by flash column chromatography to yield $0.31 \mathrm{~g}$ chiral bicyclic thiourea $2 \mathbf{a}$ as pale yellow powder. 


\subsection{Preparation of TMS-Protected Pyrrolidine 3a}

To a solution of 1a $(1.44 \mathrm{~g}, 4.0 \mathrm{mmol})$ in anhydrous $\mathrm{CH}_{2} \mathrm{Cl}_{2}(20.0 \mathrm{~mL})$ and 2,6-lutidine $(5.0 \mathrm{~mL})$ added dropwise TMSOTf ( $2.5 \mathrm{~mL}, 12.5 \mathrm{mmol}$, CAUTION! TMSOTf is a highly corrosive and moisture sensitive reagent) at $0^{\circ} \mathrm{C}$ and the mixture was stirred for $1.0 \mathrm{~h}$ at r.t. The reaction mixture was recooled to $0^{\circ} \mathrm{C}$ and quenched by addition of saturated $\mathrm{NH}_{4} \mathrm{Cl}$ solution $(2.0 \mathrm{~mL})$. The mixture was diluted by $60.0 \mathrm{~mL} \mathrm{CH} \mathrm{Cl}_{2}$ and washed by saturated $\mathrm{NH}_{4} \mathrm{Cl}$ solution $(2 \times 20 \mathrm{~mL})$, water $(2 \times 20 \mathrm{~mL})$ and brine $(2 \times 20 \mathrm{~mL})$. The organic layer was dried over anhydrous $\mathrm{Na}_{2} \mathrm{SO}_{4}$ and the solvent was evaporated to give TMS protected pyrrolidine $3 \mathbf{a}$ as brown oil in quantitative yield $(1.28 \mathrm{~g})$. The product was directly used in the next step without further purification. ${ }^{1} \mathrm{H}$ NMR $(500$ $\left.\mathrm{MHz}, \mathrm{CDCl}_{3}\right): \delta_{\mathrm{H}} 7.51-7.12(m, 12 \mathrm{H}, \mathrm{ArH}), 6.71-6.68$ (m, 1H, ArH), $6.54-6.52(m, 2 \mathrm{H}, \mathrm{ArH}), 4.28(m, 1 \mathrm{H})$, $3.54(\mathrm{~m}, 1 \mathrm{H}), 3.03(\mathrm{~m}, 1 \mathrm{H}), 2.80(\mathrm{~m}, 1 \mathrm{H}), 1.75-1.67(m$, $3 \mathrm{H}$, cyclic-H), $1.14-1.09$ ( $m, 1 \mathrm{H}$, cyclic-H), $-0.090(s$, $9 \mathrm{H}, 3 \mathrm{CH}_{3} \mathrm{Si}$ ).

\subsection{Preparation of TMS-Thiourea 4a}

(5S,7aR)-Hexahydro-5-(trimethylsiloxydiphenylmethy 1)-2-phenylpyrrolo(1,2-e)imidazole-3-thione (4a)

To a solution of $3 \mathrm{a}(1.3 \mathrm{~g}, 3.0 \mathrm{mmol})$ in anhydrous $\mathrm{CH}_{2} \mathrm{Cl}_{2}(60.0 \mathrm{~mL})$ and $N, N$-diisopropylethylamine (DIPEA, Hünig's base, $15 \mathrm{mmol}$ ) added dropwise thiophosgene $(0.24 \mathrm{~mL}, 3.3 \mathrm{mmol}$, CAUTION! Thiophosgene is a highly corrosive and toxic reagent) at $0^{\circ} \mathrm{C}$ and the mixture was stirred for $8.0 \mathrm{~h}$ at r.t. The reaction was examined by TLC. After the reaction was finished, $1.0 \mathrm{~mL}$ $\mathrm{H}_{2} \mathrm{O}$ was added to the reaction mixture. The organic layer was washed by water $(2 \times 20 \mathrm{~mL})$ and brine $(2 \times 20 \mathrm{~mL})$, and dried over anhydrous $\mathrm{Na}_{2} \mathrm{SO}_{4}$. The solvent was evaporated under reduced pressure to give the crude product 4a as yellow wax in $89 \%$ yield $(1.26 \mathrm{~g})$. The product was directly used in the next step without further purification. HRMS (ESI): Found [M+1] $]^{+} 472.2000$, Calc. for $\mathrm{C}_{28} \mathrm{H}_{32} \mathrm{~N}_{2} \mathrm{OSiS}:[\mathrm{M}+1]^{+} 472.2005 ;{ }^{1} \mathrm{H}$ NMR $(500 \mathrm{MHz}$, $\left.\mathrm{CDCl}_{3}\right): \delta_{\mathrm{H}} 7.65-7.15(m, 15 \mathrm{H}, \mathrm{ArH}), 5.19(m, 1 \mathrm{H}), 4.07$ $(m, 1 \mathrm{H}), 3.45(m, 1 \mathrm{H}), 2.90(m, 1 \mathrm{H}$, cyclic-H), $2.37(m$, $1 \mathrm{H}$, cyclic-H), $1.43(m, 1 \mathrm{H}$, cyclic-H), $0.28(m, 1 \mathrm{H}$, cyclic- $\mathrm{H}),-0.14\left(s, 9 \mathrm{H}, 3 \mathrm{CH}_{3} \mathrm{Si}\right) ;{ }^{13} \mathrm{C}$ NMR $(500 \mathrm{MHz}$, $\mathrm{CDCl}_{3}$ ): $\delta_{\mathrm{C}} 179.1$ (thionyl), 143.9, 141.9, 129.9, 129.8, $128.8,127.6,127.5,127.3,127.2,127.0,125.4,124.7$, 83.5, 64.9, 63.6, 54.9, 33.3, 25.1, 2.0 (TMS).

\subsection{Preparation of Chiral Bicyclic Thiourea 2a}

(5S,7aR)-Hexahydro-5-(hydroxydiphenylmethyl)-2-ph enylpyrrolo(1,2-e)imidazole-3-thione (2a)

To a solution of $4 \mathrm{a}(1.1 \mathrm{~g}, 2.3 \mathrm{mmol})$ in anhydrous THF $(30 \mathrm{~mL})$ added tetrabutylammonium fluoride (TBAF,
$1.4 \mathrm{~g}$ ) and the mixture was stirred for $2.0 \mathrm{~h}$ at $0^{\circ} \mathrm{C}$. The reaction was examined by TLC. After the reaction was finished, the solvents were removed under reduced pressure and the residue was dissolved in $150.0 \mathrm{~mL}$ ethyl acetate. The organic layer was washed by water $(2 \times 30$ $\mathrm{mL})$ and brine $(2 \times 30 \mathrm{~mL})$, and dried over anhydrous $\mathrm{Na}_{2} \mathrm{SO}_{4}$. The solvent was evaporated under reduced pressure to give the crude product as yellow foam which was purified by flash column chromatography ( $n$-hex/ EtOAc $=5: 1, \mathrm{~V} / \mathrm{V}$ ) to yield chiral bicyclic thiourea $2 \mathbf{a}$ as pale yellow powder in $94 \%$ yield $(0.87 \mathrm{~g}) . \mathrm{mp} 180^{\circ} \mathrm{C}$ $182^{\circ} \mathrm{C} ;[\alpha]_{D}{ }^{25}+77.2^{\circ}$ (c 1.0, $\mathrm{CHCl}_{3}$ ); HRMS (ESI): Found $\left[\mathrm{M}+\mathrm{H}-\mathrm{H}_{2} \mathrm{O}\right]^{+} 383.1592$, Calc. for $\mathrm{C}_{25} \mathrm{H}_{23} \mathrm{~N}_{2} \mathrm{~S}$ : $\left[\mathrm{M}+\mathrm{H}-\mathrm{H}_{2} \mathrm{O}\right]^{+} 383.1582 ;{ }^{1} \mathrm{H}$ NMR $\left(500 \mathrm{MHz}, \mathrm{CDCl}_{3}\right): \delta_{\mathrm{H}}$ 7.58 - $7.27(m, 15 \mathrm{H}, \mathrm{ArH}), 5.03-5.01(m, 1 \mathrm{H}), 4.23-4.16$ $(m, 1 \mathrm{H}), 3.73-3.70\left(d d, 1 \mathrm{H}, J_{1}=7.5 \mathrm{~Hz}, J_{2}=1.5 \mathrm{~Hz}\right)$, $3.29-3.24\left(d d, 1 \mathrm{H}, J_{1}=9.0 \mathrm{~Hz}, J_{2}=3.5 \mathrm{~Hz}\right), 2.45-2.36$ ( $m, 2 \mathrm{H}$, cyclic-H), $1.72-1.67$ (m, $1 \mathrm{H}$, cyclic-H), $0.96-$ $0.88\left(\mathrm{~m}, 1 \mathrm{H}\right.$, cyclic-H). ${ }^{13} \mathrm{C}$ NMR $\left(500 \mathrm{MHz}, \mathrm{CDCl}_{3}\right): \delta_{\mathrm{C}}$ 179.7 (thionyl), 146.5, 143.9, 141.2, 128.8, 128.6, 128.0, $127.2,126.6,125.4,82.8,65.0,64.7,55.7,33.6,25.8$.

The X-ray crystallographic data for chiral bicyclicthiourea $2 \mathbf{a}$ are summarized in Table 2.

The chiral bicyclic thiourea $\mathbf{2 b}$ was prepared by the same procedure as the preparation of $2 \mathbf{a}$ in $82 \%$ yield.

(5R,7aS)-Hexahydro-5-(hydroxydiphenylmethyl)-2phenylpyrrolo(1,2-e)imidazole-3-thione (2b)

Overall yield $82 \%$; pale yellow powder; $\mathrm{mp} 205^{\circ} \mathrm{C}$ $207^{\circ} \mathrm{C}$; $[\alpha]_{D}{ }^{25}-77.0^{\circ}\left(c 1.0, \mathrm{CHCl}_{3}\right)$; HRMS (ESI): Found $[\mathrm{M}+1]^{+} 401.1693$, Calc. for $\mathrm{C}_{25} \mathrm{H}_{25} \mathrm{~N}_{2} \mathrm{OS}:[\mathrm{M}+1]^{+}$ 401.1688; ${ }^{1} \mathrm{H}$ NMR $\left(500 \mathrm{MHz}, \mathrm{CDCl}_{3}\right): \delta_{\mathrm{H}} 7.58-7.28(m$, $15 \mathrm{H}, \mathrm{ArH}), 5.03-5.00(\mathrm{~m}, 1 \mathrm{H}), 4.22-4.14(\mathrm{~m}, 1 \mathrm{H}), 3.73-$ $3.70\left(d d, 1 \mathrm{H}, J_{1}=7.5 \mathrm{~Hz}, J_{2}=1.5 \mathrm{~Hz}\right), 3.29-3.24(d d, 1 \mathrm{H}$, $\left.J_{1}=8.5 \mathrm{~Hz}, J_{2}=3.5 \mathrm{~Hz}\right), 2.46-2.38(m, 2 \mathrm{H}$, cyclic- $\mathrm{H})$, $1.71-1.67(m, 1 \mathrm{H}$, cyclic-H), $0.94-0.87(m, 1 \mathrm{H}$, cyclic-H); ${ }^{13} \mathrm{C}$ NMR (500 MHz, $\mathrm{CDCl}_{3}$ ): $\delta_{\mathrm{C}} 179.8$ (thionyl), $146.5,143.9,141.0,128.7,128.6,128.1,127.2,126.6$, $125.4,82.8,65.1,64.7,55.6,33.6,25.8$.

\subsection{Supporting Information Available}

The crystallographic data can be obtained free of charge via www.ccdc.cam.ac.uk/data_request/cif, or by emailing data_request@ccdc.cam.ac.uk, or by contacting the Cambridge Crystallographic Data Centre, 12, Union Road, Cambridge CB2 1EZ, UK; fax +44-1223-336033. CCDC no. 694268 .

\section{Conclusion}

In summary, we provide an efficient and practical synthetic route to the novel chiral bicyclic thioureas 2a and 2b based on backbone of enantiopure unsymmetric cis-2, 5 -disubstituted pyrrolidines $\mathbf{1 a}$ and $\mathbf{1} \mathbf{b}$ by three steps in good yields, and the absolute configurations of $2 \mathbf{a}$ was 
determined by X-ray single-crystal diffraction analysis. The applications of these novel chiral thioureas in organic synthesis were currently studied in our laboratory.

\section{Acknowledgements}

We would like to thank the National Science Foundation of China (NSFC 20802092) for financial support of this work.

\section{REFERENCES}

[1] Z. Chai and G. Zhao, "Efficient Organocatalysts Derived from Simple Chiral Acyclic Amino Acids in Asymmetric Catalysis," Catalysis Science \& Technology, Vol. 2, No. 1, 2012, pp. 29-41. doi:10.1039/c1cy00347j

[2] S. Varga, G. Jakab, L. Drahos, T. Holczbauer, M. Czugler and T. Soós, "Double Diastereocontrol in Bifunctional Thiourea Organocatalysis: Iterative Michael-MichaelHenry Sequence Regulated by the Configuration of Chiral Catalysts," Organic Letters, Vol. 13, No. 20, 2011, pp. 5416-5419. doi:10.1021/ol201559j

[3] Y. M. Lee, R. S. Klausen and E. N. Jacobsen, "Thiourea-Catalyzed Enantioselective Iso-Pictet-Spengler Reactions," Organic Letters, Vol. 13, No. 20, 2011, pp. 55645567. doi:10.1021/ol202300t

[4] K. Hu, T. Liu, A. D. Lu, Y. Liu, Y. Wang, G. Wu, Z. Zhou and C. Tang, "Chiral Thiourea-Catalyzed Asymmetric Michael Addition of $\beta$-Oxo Phosphonate to Nitro Olefins: Convenient Synthesis of Optically Active $\beta$-Oxo Phosphonates," European Journal of Organic Chemistry, Vol. 2011, No. 19, 2011, pp. 3507-3513. doi:10.1002/ejoc.201100029

[5] N. Jia, J. Huang, L. Peng, L. L. Wang, J. F. Bai, F. Tian, G. Y. He, X. Y. Xu and L. X. Wang, "Asymmetric Hydroxyamination of Oxindoles Catalyzed by Chiral Bifunctional Tertiary Amine Thiourea: Construction of 3-Amino-2-oxindoles with Quaternary Stereocenters," Organic \& Biomolecular Chemistry, Vol. 10, No. 2, 2012, pp. 236-239. doi:10.1039/c1ob06413d

[6] M. S. Taylor and E. N. Jacobsen, "Asymmetric Catalysis by Chiral Hydrogen-Bond Donors," Angewandte Chemie International Edition, Vol. 45, No. 10, 2006, pp. 15201543. doi:10.1002/anie.200503132

[7] A. G. Doyle and E. N. Jacobsen, "Small-Molecule H-Bond Donors in Asymmetric Catalysis," Chemical Reviews, Vol. 107, No. 12, 2007, pp. 5713-5743. doi: $10.1021 / \mathrm{cr} 068373 \mathrm{r}$

[8] R. R. Knowles and E. N. Jacobsen, "Attractive Noncovalent Interactions in Asymmetric Catalysis: Links between Enzymes and Small Molecule Catalysts," PNAS, Vol. 107, No. 48, 2010, pp. 20678-20685. doi:10.1073/pnas.1006402107

[9] M. J. Dai, B. Liang, C. Wang, Z. You, J. Xiang, G. Dong, J. Chen and Z. Yang, "A Novel Thiourea Ligand Applied in the Pd-Catalyzed Heck, Suzuki and Suzuki Carbonylative Reactions," Advanced Synthesis \& Catalysis, Vol. 346, No. 13-15, 2004, pp. 1669-1673. doi:10.1002/adsc. 200404165

[10] W. Chen, R. Li, B. Han, B. J. Li, Y. C. Chen, Y. Wu, L. S. Ding and D. Yang, "The Design and Synthesis of Bis(thiourea) Ligands and Their Application in Pd-Catalyzed Heck and Suzuki Reactions under Aerobic Conditions," European Journal of Organic Chemistry, Vol. 2006, No. 5, 2006, pp. 1177-1184. doi:10.1002/ejoc.200500644

[11] Y. Lan, L. J. Deng, J. Liu, C. Wang, O. Wiest, Z. Yang and Y. D. Wu, "On the Mechanism of the Palladium Catalyzed Intramolecular Pauson-Khand-Type Reaction," Journal of Organic Chemistry, Vol. 74, No. 14, 2009, pp. 5049-5058. doi:10.1021/j0900919v

[12] B. Liang, J. Liu, Y. X. Gao, K. Wongkhan, D. X. Shu, Y. Lan, A. Li, A. S. Batsanov, J. A. H. Howard, T. B. Marder, J. H. Chen and Z. Yang, "Synthesis of Thiourea-Oxazolines, a New Class of Chiral S,N-Heterobidentate Ligands: Application in Pd-Catalyzed Asymmetric Bis(methoxycarbonylation) of Terminal Olefins," Organometallics, Vol. 26, No. 19, 2007, pp. 4756-4762. doi:10.1021/om700311x

[13] D. Cauzzi, M. Costa, N. Cucci, C. Graiff, F. Grandi, G. Predieri, A. Tiripicchio and R. Zanoni, "Pd(II) and Rh(I) Chelate Complexes of the Bidentate Phosphino-Thiourea Ligand $\mathrm{PhNHC}(\mathrm{S}) \mathrm{NHCH}_{2} \mathrm{CH}_{2} \mathrm{PPh}_{2}$ : Structural Properties and Activity in Homogeneous and Hybrid Catalysis," Journal of Organometallic Chemistry, Vol. 593-594, No. 1, 2000, pp. 431-444. doi:10.1016/S0022-328X(99)00615-4

[14] R. Abdallah, J. A. J. Breuzard, M. C. Bonnet and M. Lemaire, "Phosphite and Thiourea Ligand Synergy for Rhodium Catalyzed Enantioselective Hydroformylation of Styrene," Journal of Molecular Catalysis A: Chemical, Vol. 249, No. 1-2, 2006, pp. 218-222. doi:10.1016/j.molcata.2005.12.020

[15] E. M. O. Yeboah, S. O. Yeboah and G. S. Singh, "Recent Applications of Cinchona Alkaloids and their Derivatives as Catalysts in Metal-free Asymmetric Synthesis," Tetrahedron, Vol. 67, No. 10, 2011, pp. 1725-1762. doi:10.1016/j.tet.2010.12.050

[16] T. Zhang, L. Cheng, S. Hameed, L. Liu, D. Wang and Y. J. Chen, "Highly Enantioselective Michael Addition of 2-Oxindoles to Vinyl Selenone in RTILs Catalyzed by a Cinchona Alkaloid-Based Thiourea," Chemical Communications, Vol. 47, No. 23, 2011, pp. 6644-6646. doi:10.1039/c1cc10880h

[17] M. M. S. Duque, O. Baslé, N. Isambert, A. Gaudel-Siri, Y. Génisson, J. C. Plaquevent, J. Rodriguez and T. Constantieux, "A Cooperative Participation of the Amido Group in the Organocatalytic Construction of All-Carbon Quaternary Stereocenters by Michael Addition with $\beta$-Ketoamides," Organic Letters, Vol. 13, No. 13, 2011, pp. 3296- 3299. doi:10.1021/ol200924e

[18] C. Kanta De and D. Seidel, "Catalytic Enantioselective Desymmetrization of meso-Diamines: A Dual Small-Molecule Catalysis Approach," Journal of the American Chemical Society, Vol. 133, No. 37, 2011, pp. 14538-14541. doi:10.1021/ja2060462

[19] A. E. Nowak, E. Wojaczyńska and J. Skarżewski, "Enantiopure trans-1-Amino-2-(arylsulfanyl)cyclohexanes: Novel 
Chiral Motifs for Ligands and Organocatalysts," Tetrahedron: Asymmetry, Vol. 22, No. 16-17, 2011, pp. 16871691. doi:10.1016/i.tetasy.2011.09.015

[20] J. Wang, H. Li, X. H. Yu, L. S. Zu and W. Wang, "Chiral Binaphthyl-Derived Amine-Thiourea Organocatalyst-Promoted Asymmetric Morita-Baylis-Hillman Reaction," Organic Letters, Vol. 7, No. 19, 2005, pp. 4293-4296. doi:10.1021/o1051822+

[21] M. Shi and X. G. Liu, "Asymmetric Morita-Baylis-Hillman Reaction of Arylaldehydes with 2-Cyclohexen-1-one Catalyzed by Chiral Bis(Thio)urea and DABCO," Organic Letters, Vol. 10, No. 6, 2008, pp. 1043-1046. doi:10.1021/o17028806

[22] K. Liu, H. F. Cui, J. Nie, K. Y. Dong, X. J. Li and J. A. Ma, "Highly Enantioselective Michael Addition of Aromatic Ketones to Nitroolefins Promoted by Chiral Bifunctional Primary Amine-Thiourea Catalysts Based on Saccharides," Organic Letters, Vol. 9, No. 5, 2007, pp. 923-925. doi:10.1021/o10701666

[23] P. Gao, C. G. Wang, Y. Wu, Z. H. Zhou and C. C. Tang "Sugar-Derived Bifunctional Thiourea Organocatalyzed Asymmetric Michael Addition of Acetylacetone to Nitroolefins," European Journal of Organic Chemistry, Vol. 2008, No. 27, 2008, pp. 4563-4566. doi:10.1002/ejoc. 200800555

[24] S. V. Pansare and E. K. Paul, "Organocatalytic Asymmetric Direct Vinylogous Aldol Reactions of $\gamma$-Crotonolactone with Aromatic Aldehydes," Chemical Communications, Vol. 47, No. 3, 2011, pp. 1027-1029. doi:10.1039/c0cc04191b

[25] P J. Y. Fu, Q. C Huang, Q. W. Wang, L. X. Wang and $\mathrm{X}$. Y. Xu, "Highly Effective and Enantioselective $\alpha$-Amination of Aldehydes Promoted by Chiral Proline AmideThiourea Bifunctional Catalysts," Tetrahedron Letters, Vol. 51, No. 37, 2010, pp. 4870-4873. doi:10.1016/j.tetlet.2010.07.042

[26] C. L. Cao, M. C. Ye, X. L. Sun and Y. Tang, "Pyrrolidine-Thiourea as a Bifunctional Organocatalyst: Highly Enantioselective Michael Addition of Cyclohexanone to Nitroolefins," Organic Letters, Vol. 8, No. 14, 2006, pp. 2901-2904. doi:10.1021/o1060481c

[27] P. A. Wang, Z. S; Xu, C. F. Chen, X. G. Gao, X. L. Sun and S. Y. Zhang, "Facile Synthetic Route to Enantiopure Unsymmetric cis-2,5-Disubstituted Pyrrolidines," Chirality, Vol. 19, No. 7, 2007, pp. 581-588. doi:10.1002/chir.20424

[28] P. A. Wang, W. He, S. K. Chen and S. Y. Zhang, "Efficient Synthesis of Unnatural Dipeptides Based on cis-2,5Disubstituted Pyrrolidine," Amino Acids, 2011, in press. doi:10.1007/s00726-011-0949-4

[29] E. J. Corey, H. Cho, C. Rcker and D. H. Hua, "Studies with Trialkylsilyltriflates: New Syntheses and Applications," Tetrahedron Letters, 1981, Vol. 22, No. 36, pp. 3455-3458. doi:10.1016/S0040-4039(01)81930-4 